\title{
An Investigation of the Communicative Approach Teaching in Primary English Textbooks in Hong Kong and Malaysia: A Search into Communicative Language Teaching (CLT) Textbooks, And How CLT is Applied in Textbooks
}

\author{
Charles Ko \\ Open University of Hong Kong \\ E-mail: ko_kashing@hotmail.com
}

Received: 07-11- 2013

Accepted: $26-12-2013$

Published: 31-01-2014

doi:10.7575/aiac.ijels.v.2n.1p.63

URL: http://dx.doi.org/10.7575/aiac.ijels.v.2n.1p.63

\begin{abstract}
In the present research, it will be shown how grammar activities in textbooks still retain the structural method of teaching grammar. The results found by previous scholars' research will be covered, and illustrated by excerpts of textbooks, including comparison of Hong Kong and Malaysian textbooks. Communicative Language Teaching (CLT) materialized in the West in the 1960s, and has extended to the Eastern countries over the last 20 years (Chung, 2005: 33). Since the introduction of CLT, many English textbooks have been published to incorporate communicative activities, authentic material and personalized contexts, however, most of the learning and teaching of grammar in textbooks do not fully reflect CLT principles (ibid.). The paper is written to show concerns over textbook designing issues and hence provide recommendations in changing the design of the modern English language textbooks. In the end of the paper, this research will suggest methods of designing more communicative grammar activities in English language textbooks for future textbook designers having guidelines in compiling the CLT English language textbooks. Besides, some approaches of communicative teaching with the CLT textbooks will be recommended to the pre- and inservice English language teachers in order to lead them to the current trend of CLT.
\end{abstract}

Keywords: Communicative Language Teaching (CLT), Audiolingual Method, Textbook, Throw-Away Materials, Games

\section{Introduction}

\subsection{What Is Communicative Language Teaching?}

"Communicative Language Teaching (CLT) materialized in the West in the 1960s and has extended to the Eastern countries over the last 20 years" (Chung, 2005: 33).

We may prefer to regard CLT as an approach to language teaching more than only a method (e.g. Richards \& Rodgers, 2001), which the approach should be based on the rationales that the fundamental function of language use is communication instead of studies of grammar. While its chief goal is for learners developing "communicative competence" (Hymes, 1971), in other words to improve the communicative ability, making use of real-life situations that necessitate communication will be the consequence of this type of learning.

Nowadays, CLT principles may have formed the foundation of English language syllabi for countries worldwide (cf. Chung, 2005: 33). CLT is adopted in Malaysia, and it was adopted in there in "as early as the 1970s" (ibid.). Within the educational framework of Hong Kong, the switch from the structural to communicative approach in primary syllabi is believed to be re-started by the 2004 curriculum reform (for details of the primary textbook regulations, cf. Curriculum Development Council, 2004: 211-212).

\subsubsection{Trends in CLT}

The notion of communicative competence (Hymes, 1971) is one of a large number of theories that underlie the communicative approach to foreign language teaching (Leung, 2005): Canale \& Swain (1980) once defined communicative competence in terms of three components:

1. "grammatical competence: words and rules

2. sociolinguistic competence: appropriateness

3. strategic competence: appropriate use of communication strategies"

Recent years, a survey, which is in contrast to previous views in which grammatical competence was commonly given top priority, of "communicative competence" by Bachman (1990) divides the term into the two broad headings: "organizational competence," which includes both grammatical and discourse (or textual) competence, and "pragmatic 
competence", which includes both sociolinguistic and illocutionary competence. The critical point of view of this recent survey is the emphasis on the actual use of language which leads the current trend to the development of CLT as the goal of language education, in which the design of CLT textbook is involved as one of the elements, and that is why the textbook analysis research projects exist (cf. Chung, 2005).

\section{Theoretical Framework}

\subsection{Background}

2.1.1 What was the mainstream approach in Asian education before CLT, and what make the CLT become essential?

"The structural syllabus was the mainstream approach in most Asian settings" before CLT was introduced (Chung, 2005: 33). We may be inspired by the quote of Yalden (1987: 61) which emphasizes the essence of CLT:

"It is based on the notion of the learners as communicators, naturally endowed with the ability to learn languages. It seeks to provide learners with the target language system. It is assumed that learners will have to prepare to use the target language (orally and in written form) in many predictable and unpredictable acts of communication which arise both in classroom interaction and in real-world situations, whether concurrent with language training or subsequent to it."

\subsubsection{What is CLT? What are its principles in textbook?}

\subsubsection{A relationship between Structural syllabus and Communicative syllabus}

"The structural view of language sees grammatical structures as the underlying units of the language system [in which these] units of language are structurally rule-governed" (Chung, 2005: 34). The audiolingual method is derived from the structural view and it was practiced in many Asian countries or regions such as Malaysia, Taiwan, and Hong Kong before the implementation of the CLT. This audiolingual method comprises activities that focus on correct pronunciation, spelling convention and grammatical forms (ibid.). Drills are frequently used in the audiolingual classroom because repetition and memorization (for the purpose of accuracy) are believed to be important.

CLT emphasizes learner-centeredness and the use of original material (ibid.). Referred to CLT, the original material is the powerful tool for the communicative classroom: in textbook, it is accordingly encouraged to cover the original material in textbook design. According to Howatt (1984), CLT is divided into strong and weak versions. 'The strong version is in support of communicative features whereas the weak version suggests the integration of structural practice into the communicative elements' (ibid., as cited in Chung, 2005). In other words, in strong version, the original material is strongly encouraged to use in textbook while it is not that important in the week version of CLT.

In a survey carried out by Maley (1986: 104) on the Chinese learners in mainland China, it was found that the interviewees view teacher as the "textbook" or the guru that "has the knowledge". Therefore, to learn means to convert knowledge in the textbooks into memory. This result makes a great influence on the design of Asian textbook, that many textbooks are still largely based on structural syllabi instead of communicative syllabi, because the learners believe covering more grammatical rules in textbook can let them memorize more accurate grammar, as a result most textbooks adopted in China, and the schools in the northern parts of New Territories in Hong Kong (in the northern schools of Hong Kong, there are majority of students come from mainland China; in primary education, the numbers of children from the mainland newly admitted are 10,545, 3,282, and 2,895 in academic years 2006/07, 2010/11, and 2011/12 respectively, for details see Table 1 below) are mainly based on the weak version of CLT, that the textbook designer 'integrates the structural practice into the communicative elements' (Howatt, 1984), instead of the strong version of CLT.

Table 1. Data about the primary education in Hong Kong

\section{Primary Education}

\begin{tabular}{|c|c|c|c|}
\hline & \multicolumn{3}{|c|}{ School/Academic year } \\
\hline & $2006 / 07$ & 2010/11 & $2011 / 12$ \\
\hline $\begin{array}{l}\text { No. of Schools } \\
\text { - Local } \\
\text { - ESF \& other international }\end{array}$ & $\begin{array}{r}620 \\
48\end{array}$ & $\begin{array}{r}532 \\
40\end{array}$ & $\begin{array}{r}528 \\
40\end{array}$ \\
\hline - Total & $\underline{668}$ & $\underline{572}$ & $\underline{568}$ \\
\hline Student Enrolment ${ }^{(1)}$ & 410516 & 331112 & 322881 \\
\hline No. of Repeaters ${ }^{(1)}$ & 3729 & 2470 & 2347 \\
\hline No. of Children from the Mainland Newly Admitted ${ }^{(2) /(3)}$ & 10545 & 3282 & 2895 \\
\hline Average Class Size ${ }^{(2)}$ & 32.2 & 28.9 & 28.2 \\
\hline
\end{tabular}

Source: Education Bureau, http://www.edb.gov.hk/en/about-edb/publications-stat/figures/pri.html, retrieved April 24, 2013. 
2.1.2.2 Peeking into Hong Kong and Malaysian Textbooks

The Hong Kong's English language syllabus is outlined by the Curriculum Development Council (CDC) of Hong Kong. The objectives to apply communicative approach in English language teaching can be seen in the 6.1.1 Choosing Textbooks of the CDC published English Language Curriculum Guide (Primary 1-6) in 2004 (Curriculum Development Council, 2004):

"[...] schools should consider the following when choosing textbooks:

whether:

- the textbooks provide quality resources for a task-based approach in learning, teaching and assessment in English;

- there is a balanced coverage between the learning and teaching of language forms (e.g. text types, vocabulary, grammar items and structures) and communicative functions; ...

- grammar is learned and taught in context and through tasks; ..."

(pp. 211-212)

The Malaysian English language syllabus is published by the Curriculum Development Centre of Malaysia. The attempt to incorporate communicative language teaching can be observed in the aims of the Form Four English Language Syllabus which emphasizes daily communicative and occupational needs (Ministry of Education, 1992):

"To equip them [students] with the skills and knowledge of the English language to communicate in certain everyday activities and certain job situations, and also to provide points of take-off for various post-secondary school needs..." (p. 1)

However, 'when grammar is presented in textbooks, it usually does not reflect the aim of the communicative syllabus' (Chung, 2005).

2.1.2.3 Retaining the Structural Method in textbooks

Yalden (1987: 94) proposes the course design ${ }^{1}$ that students should learn more form than meaning at an early stage and as time increases (as students' language proficiency improves), the intervention of communicative functions increases, which means that when children's language proficiency develops, the emphasis on form in language syllabi can be gradually reduced. In other words, primary English textbook should be in structural approach instead of communicative approach, due to the fact that general primary students' proficiency of English language is still not completely developed (especially true in ESL places). As a result, some part of the modern textbooks is based strongly on the audiolingual syllabus. (For illustration, some excerpts from the New Magic 5A textbook (Arnold, 2008) are adapted in Fig. 1 \& 2.) But the problem is, retaining the structural method in textbooks may not be a good way to teach a language in long term that the learners will not acquire the language in a communicative way, in the end they cannot communicate fluently.

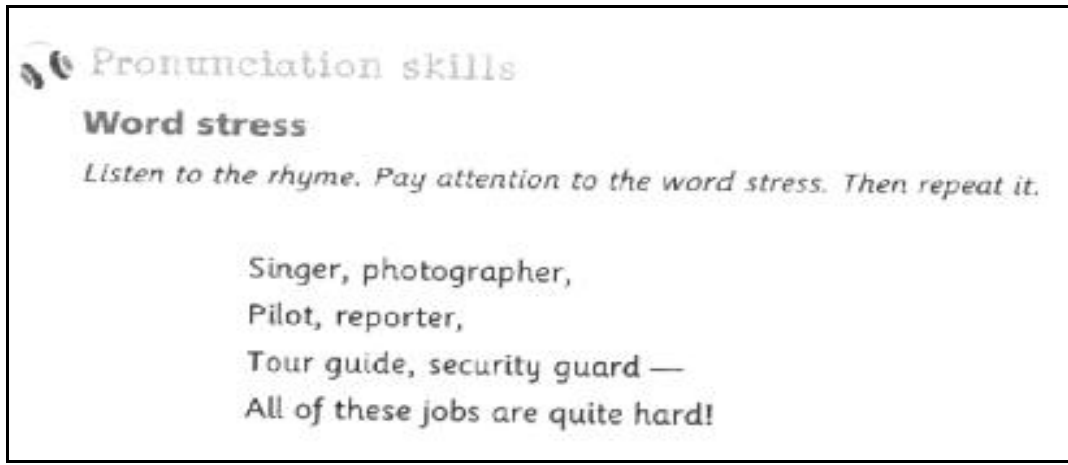

Fig. 1. An activity applied in textbook, Image source: New Magic 5A.

Peter is telling you about his family. Listen to what Peter says and write the missing words. Circle the stressed part of the words. Then read aloud what Peter says.

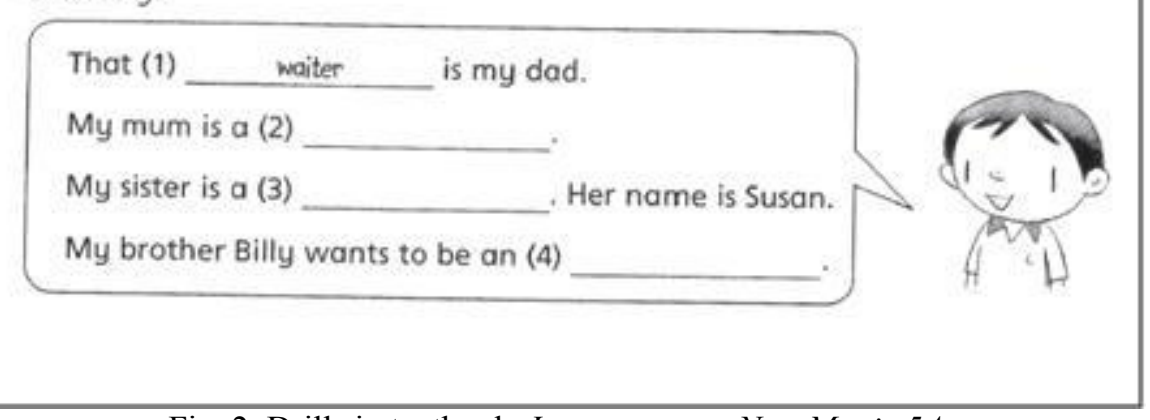

Fig. 2. Drills in textbook, Image source: New Magic $5 \mathrm{~A}$

\footnotetext{
${ }^{1}$ The design of course is based on the proportional approach (Yalden, 1987: 94).
} 
Although the fact that primary students' proficiency of English language is still not completely developed in general may affect the decision on the adoption of CLT principles in textbooks, the problem can probably be solved by integrating games into the CLT textbooks to let learners communicate in English step-by-step:

\section{A. To integrate games into the CLT textbooks}

There have been lots of research proving or stating that games can make a language textbook, hence the lesson more communicative and interactive (e.g., Rixon, 1981: 1; Lee, 1979; Uberman, 1998).

\section{Some background of games}

One distinction among games is that between competitive games and cooperative ones (Jacobs, in preparation). Research suggests that learning and affective variables are enhanced by a cooperative environment (Johnson, Johnson \& Stanne, 2000) and in addition, Millis (2005) outlines a number of advantages of cooperative games, namely appropriate anxiety levels and more constructive feedback.

\section{B. When and how to integrate games into the language curriculum}

Traditionally, games have been usually used in the language class as (1) warm-ups at the beginning of class, (2) fill-ins when there is extra time near the end of class, or as (3) an occasional bit of spice stirred into the curriculum to add variety. Nonetheless, games can and should also constitute a more substantial part of language courses (Lee, 1979; Rixon, 1981; Uberman, 1998).

In the Presentation-Practice-Production framework (Mauer, 1997), ${ }^{2}$ the games can be either for (a) practicing specific language items or skills, or (b) for more communicative language production. Besides, games can also be used as a way to revise and recycle previously taught language (Uberman, 1998).

\section{a. Modifying games as communicative activities in textbook}

To use games in the classroom, Rixon (1981: 1) suggests three key principles: (a) think about games; (b) know their ingredients and (c) know how to vary them. Sometimes, the textbook is covered games for English Language learning. However, the "games" are not communicative enough that they only involve reading and writing training, but do not cover the one of speaking and listening, and hence do not involve the balanced language skills development for teaching-learning as emphasized in the CLT approach. Therefore, teachers need to adjust the procedures of the games.

\section{b. $\quad$ Using more proper Game Activities in language teaching}

Among the purposes of the present research, the proposed research also aims to provide some suggestions for pre- and in-service English language teachers in shifting their tradition way of language teaching to a proper game-based teaching style, with their modifications of the game rules set in textbook, as a number of advantages of proper use of games in lessons are highly suggested by scholars (cf. Rixon, 1981). In the following, the purpose is to discuss reasons for using games of language. There are three major reasons of using games in language teaching:

First of all, games add interest to what students might not find very interesting. Sustaining interest can mean sustaining effort (Thiagarajan, 1999; Wright, Betteridge, \& Buckby, 2005). After all, learning a language involves long-term effort.

Second, games provide a context for meaningful communication. Even if the game, say a spelling game, involves discrete language items, meaningful communication can still take place as students seek to 'understand how to play the game and as they communicate about the game': before, during, and after the game (ibid.).

To conclude, the game can achieve meaningful communication which provides the basis for (1) comprehensible input (Krashen, 1985): i.e., what students understand as they listen and read, (2) interaction to enhance comprehensibility: e.g., asking for repetition or giving examples (Long, 1981), and (3) comprehensible output: i.e., speaking and writing so as to let others understand (Swain, 1993).

\subsection{Concluding remarks}

\section{Summary}

A. Collecting textbook excerpts for analysis

In the present study, around 10 excerpts of textbooks showing grammar activities are taken for illustration regarding the treatment of grammar teaching by textbook editors. I will especially focus on how the balance of structural and CLT syllabi by textbook editors has been done, that the data will be collected from Arnold (2008), and a number of Malaysian textbook excerpts:

Textbook mainly employed in Hong Kong primary schools

Arnold, W. (2008). What do you do? New Magic 5A. Oxford University Press (China) Ltd.

\footnotetext{
${ }^{2}$ In the Mauer's (1997, September) Presentation-Practice-Production framework, language items are first presented for students to listen to and/or read, then practiced in a manner in which the language used is controlled (e.g., students read out a dialogue from the textbook in which the two characters compare study habits) and then produced by students in a less controlled manner, e.g., two students discuss their own study habits, etc.
} 


\section{B. Project for improvements on the design of current textbooks}

a. Inclusion of the "throw-away" materials

In textbook design, there is an issue of the inclusion of the "throw-away" materials to achieve the CLT principles (e.g., Suppiah, Subramaniam, \& Michael, 2011). Workable grammar activities using "throw-away" materials can effectively help learners overcome their inhibitions in learning grammar (ibid.): the grammar activities using these materials can be a strategy which brings about a "stress-free" environment and nevertheless helps build learners' self-confidence in learning English grammar.

b. What are "throw-away" materials? (Suppiah, Subramaniam, \& Michael, 2011)

The so-called "throw-away" materials can simply mean the materials are easy to obtain, colourful, free of charge ("throw-away" materials are usually free with no cost involved, which means the teacher does not have to pay for the materials), language suitable - the language of the written texts on the "throw-away" materials for students has to be suitable for various levels of learners with different levels of proficiency; last but not least, the throw-away materials should be real-life, which means the selected materials should be the ones that the students might encounter now or situation later in real-life.

(More about the use of "throw-away" materials can be referred to section 4.2.)

\section{Limitations}

There have been several studies investigating the number of English textbooks worldwide (e.g. Chung, 2005), while the research focus of the English textbooks adopted in Hong Kong still lack in the field: although there are some research studying the presentation and treatment of vocabulary in English textbooks in Hong Kong (e.g. Or, 2010), the focus was the comparison of vocabulary teaching methods but not only on the communicative approach in textbook. Consequently, there is an essence in investigating the English textbooks in Hong Kong, and also the ones in Malaysia for making a contrast between Hong Kong's textbooks and the Malaysian ones from the communicative approach perspective.

There are more advantages than disadvantages in the use of CLT in textbooks. One way or another, the focal point of the present study is to help English language textbook designers through the discussion of what the philosophy should be involved in the designing and compiling processes of textbook. This research has to be carried out to stimulate the textbook editors in considering the involvement of teaching methods in grammar education.

\subsection{Methodology}

In comparison of the selected textbooks, a checklist will be used to evaluate the findings, the advantages of using a checklist in textbook research are shown as follows (Or, 2010):

McGrath (2002: 26-27) has suggested four advantages of using a checklist to conduct textbook evaluations:

- it is systematic, ensuring that all elements that are deemed to be important are considered

- it is cost - effective, permitting a good deal of information to be recorded in a relatively short space of time

- the information is recorded in a convenient format, allowing for easy comparison between competing sets of material

- it is explicit, and, provided the categories are well understood by all involved in the evaluation, offers a common framework for decision-making.

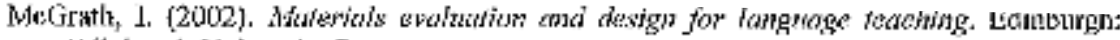
Edinburgh University Press.

\section{Procedures}

In the first step, a search into the selected Communicative Language Teaching (CLT) and non-CLT English language textbooks is to be done. Second, the questions whether the current textbooks could reflect the CLT principles and whether the textbooks are more student-based or more teacher-based designed will be examined for further evaluation.

The project will report the findings upon the examination of the selected textbooks including Arnold (2008) in Hong Kong adopted English primary textbooks. A number of evidence will be produced by the display of textbook excerpts to prove that the implementation of CLT in both Malaysian and Hong Kong settings still has little influence on the design of textbook to some extent. This project will also suggest a number of communicative methods supported by bibliography to supplement the activities designed in textbooks in order to change the activities into more communicative activities. In summary and elaboration, the following issues will be especially investigated: 
1. How can textbooks be more communicatively designed for English beginner learners?

2. What do teachers need to do to apply the CLT principles in textbook more effectively into their lessons?

Other research questions

a. What are the arguments for and against of applying the CLT principles in textbooks?

b. What may be the current Chinese students' views of the criteria of a good textbook?

\section{Results and Discussion}

\subsection{Inclusion of grammar-rule explanation, and target vocabularies and text-writing guidelines}

An analysis of the selected textbooks (mostly primary textbooks while some secondary textbooks' excerpts and the excerpts of textbooks probably adopted in other countries are also investigated for holistic view of the education systems) shows that most of the grammar activities still feature the traditional pattern rather than conforming to the principles of the communicative syllabus. Even though some parts of the textbooks attempt to integrate the communicative elements, most exercises are mainly structural with the 'inclusion of grammar-rule explanation' (Chung, 2005), as shown in Figures 3 and 4 below. Nevertheless, the textbooks usually contain the exposed target vocabularies and text-writing guidelines, that this design method is based on the structural approach (see Figures 5 and 6):

1 We use what' to ask abutit jobs.

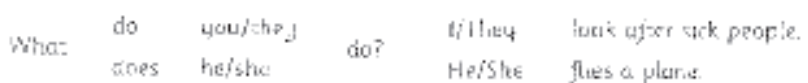

2. We use 'wnere' to nak about t'se plore of work.

where do yevithey work lithey wark in acinic.

does huiste work? Heitho wres in a spececrat:

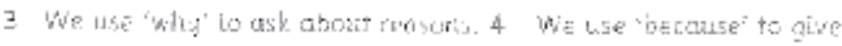

reasons.

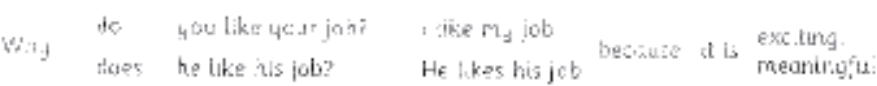

Fig. 3. An excerpt from textbook showing the inclusion of Audiolingual method (ALM) structures explanation, Image source: New Magic $5 \mathrm{~A}$

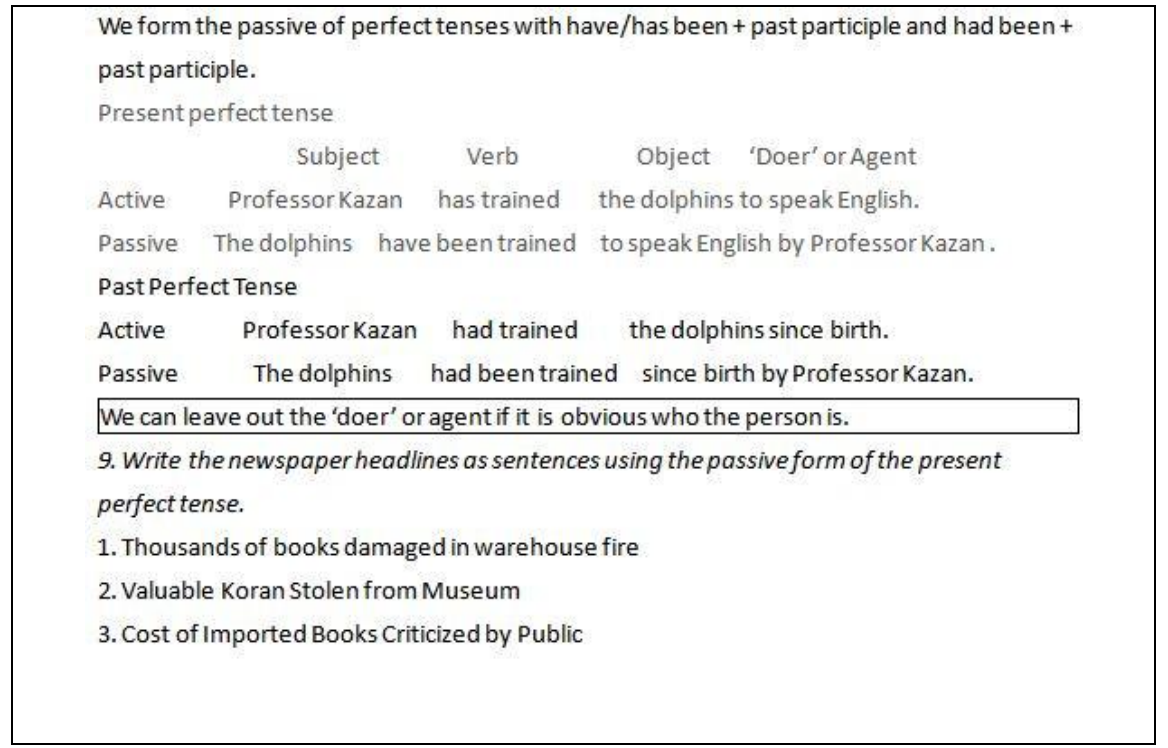

Fig. 4. A Grammar Exercise with grammar-rule explanation,

Source: Yunus \& Spykerman (1996: 211-212), as cited by Chung (2005)

\footnotetext{
${ }^{3}$ The textbook excerpt is re-typed by Chung (2005), and by the author of this paper (and it is not taken from one complete page of the textbook).
} 


\section{Your turni}

Where as these peopie wark? bo you think the like their jobs? Why?

1

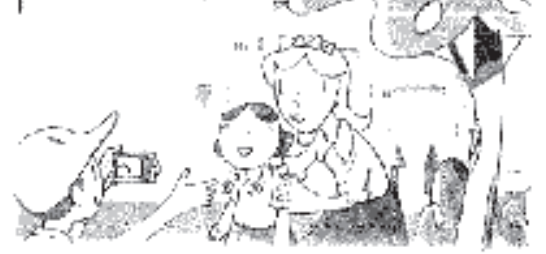

wea' a costume

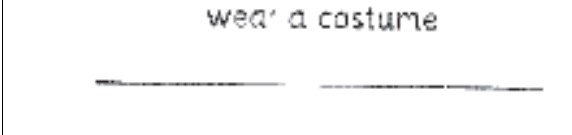

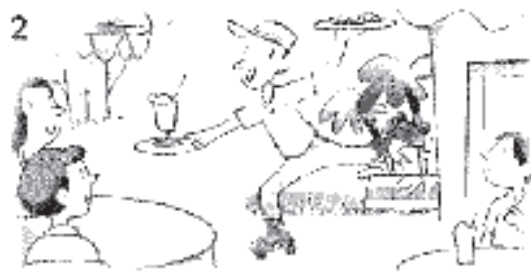

roller skate

Fig. 5. An excerpt from textbook showing the target vocabularies, Image source: New Magic 5A

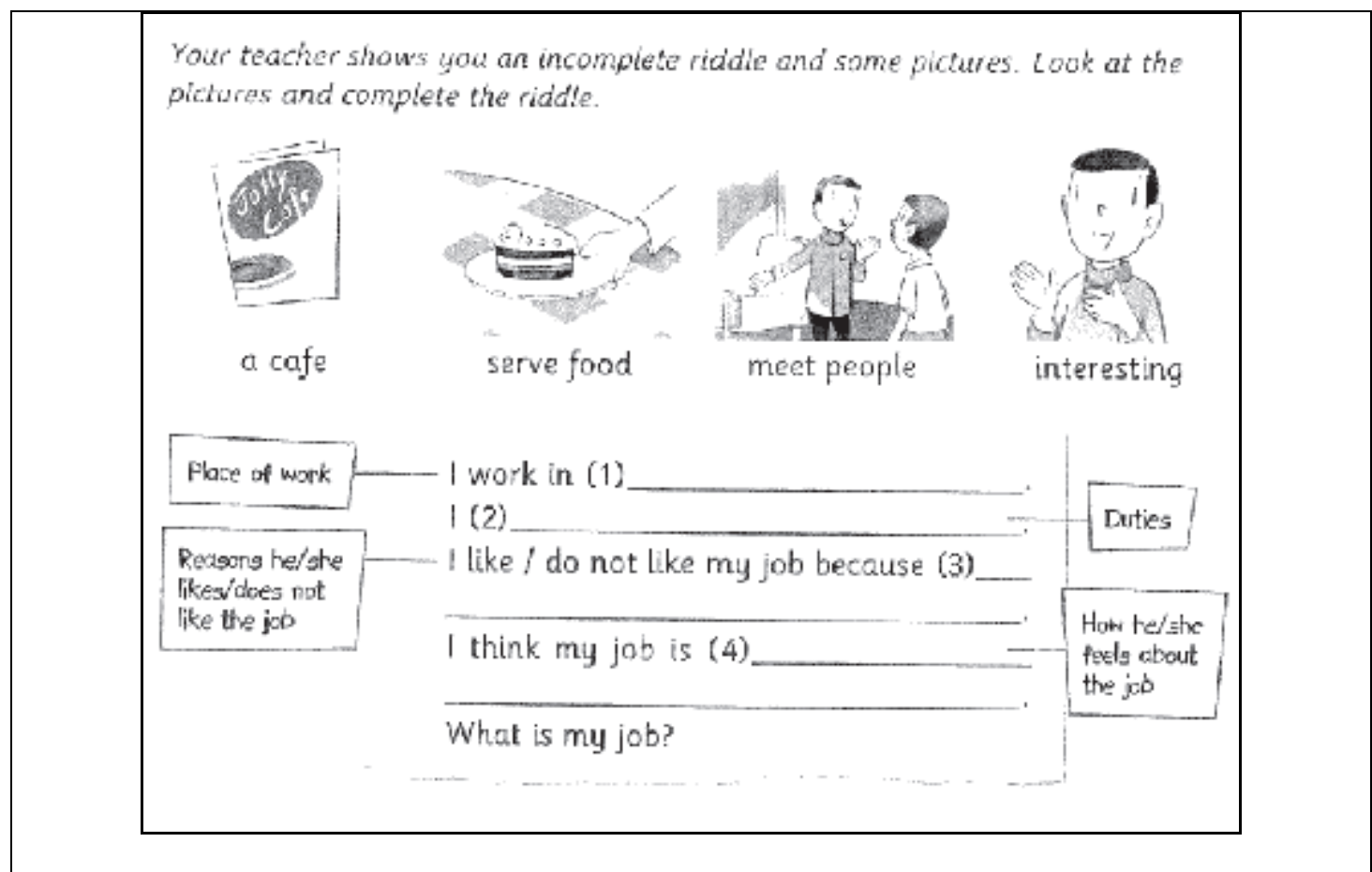

Fig. 6. An excerpt from textbook showing the inclusion of target vocabularies and text-writing guidelines, Image source: New Magic 5A

\subsection{The role of teacher}

In dealing with the principally structural textbook, teachers need to turn the material into communicative tasks. In this process, teachers need to provide pre-teaching material (Chung, 2005):

When students are not able to carry out the activity, a pre-teach stage may precede the communicative activity. Vocabulary terms such as pulled down, removed and developed can be introduced prior to the free communicative activity.

The need for "pre-communicative activity" was mentioned by Littlewood (1981) that the "pre-communicative" activities such as drills and controlled practice provide the required skills for upcoming activities (Chung, 2005: 46).

For example, in an activity of structural-approach-based textbook cited by Ur's (1988), teachers can focus on teaching the past tense and the present tense in the pre-communicative activity (Chung, 2005: 46) (see figure 7). Afterwards, students can then compare the landscapes of the Picture A and Picture B by using the tenses, e.g. students will compose the sentence 'The Island did not have the National Park and hotels, and now they exist'. 

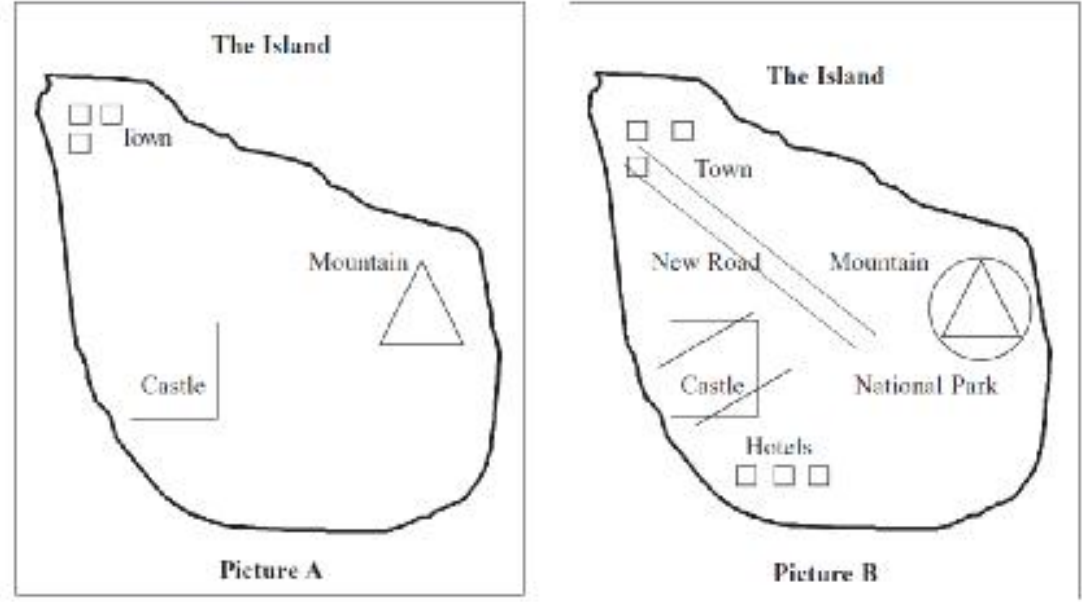

Fig. 7. Spot the changes, Image source: Ur's (1988)

3.2.1 To achieve CLT principles in designing and using textbooks with reference to scholars' advice

I. To balance communicative abilities

"When the communicative syllabus is concerned, continuity and balance in teaching the four skills are emphasized" (Chung, 2005: 47).

On one hand, it is admirable for Chang (2000) to highlight the importance of communicative skills such as "initiating, sustaining, closing a conversation" (all referred to speaking skills, and listening skills) to enhance communicative competence among Chinese students; on the other hand, we may argue against Chang's view that it overlooks the "importance of reading and writing" (Chung, 2005: 47): reading involves "real life skills" (Grant, 1987: 79), with example as in reading for gist, reading for information (ibid.); nevertheless, writing may comprise the text-writing that writing a formal letter for a job interview present in the authentic situation.

Based on the equal importance of the four skills, an activity that balances the learning of the 4 skills should be included in lesson: it is the Information Gap activity. In participating into the information gap activity of textbook, one student may have the information that another classmate lacks. In this communicative activity, students have to exchange information through oral practice in order to complete a table, paragraph, or map (e.g. the mind map drawing activity in figure 8 is a part of an information gap activity designed in the CLT textbook).

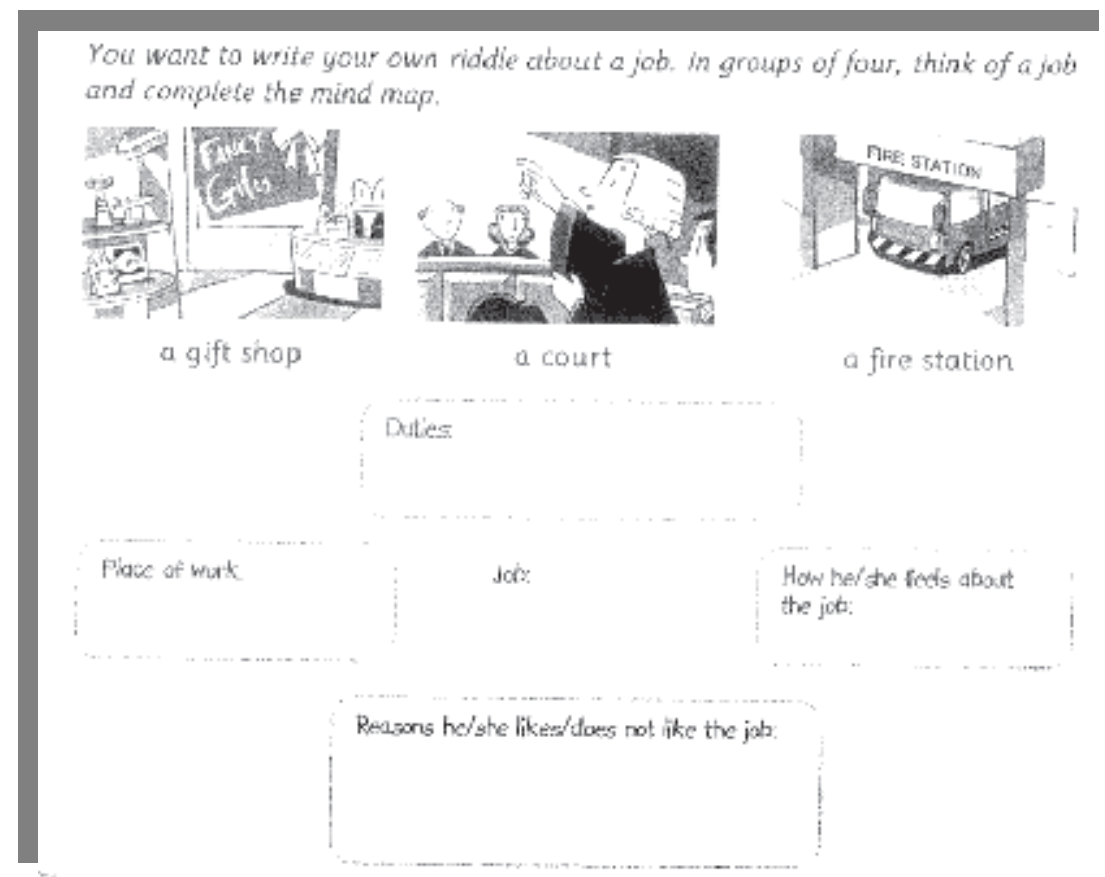

Fig. 8. Task: Draw a mind map in group activity, Image source: New Magic $5 \mathrm{~A}$

II. To personalize the textbook

A language curriculum is written based on generalisations regarding learning and usage (Finocchiaro \& Brumfit, 1983, as cited by Chung, 2005). In textbook designing, most designers will generalize the material in order to meet a variety of target learners' requirements, although there should be a need to achieve personalization in some places of textbook, as Cunningsworth (1995) mentioned that the adaptation and personalization of textbooks is necessary so as to address specific students' needs and interests.

Personalization does not mean changing the whole textbook (Chung, 2005). For instance, the following specific and indigenous names in Malaysia have been made in the Malaysian textbook in order to achieve personalization in design of textbook: 
(Yunus \& Spykerman, 1996)

"Although these [personalized] features are small, they create a sense of closeness between the students and the tasks" (Chung, 2005).

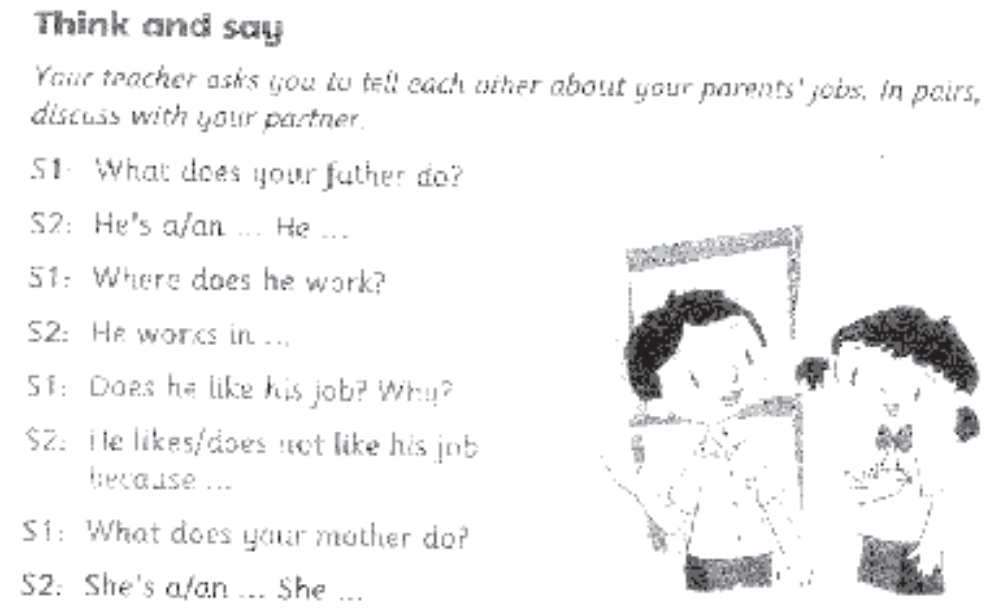

Fig. 9. A role-play of textbook that needed to be personalized by teacher to achieve CLT principle, Image source: New Magic 5A

Apart from the responsibility of textbook designers for the personalization, teachers should also be responsible to personalize the generalized contents in textbooks to achieve a communicative activity. For example, see the textbook excerpt in figure 9 above, the textbook can successfully achieve the communicative aim of the syllabus only when teacher cooperatively uses the names of his students instead of the generalized common names (e.g. Peter, Tom, Sally, etc.) It is more interesting by transforming the $S 1, S 2$ into the names of partners in the pairs. This learning process can add fun and reduce fears of learning a language (Chung, 2005).

III. To adjust the teacher role and textbook use

Even though CLT proposes that teachers should step back and 'make space for the learners' (Spaventa, 1980, as cited by Littlewood, 1992: 98), the thorough lessening of teacher control may not be possible: a variable Control-andWarmth approach (Borich \& Tombari, 1995: 302) may be needed to be adopted, i.e. some classes may employ a HighControl-Low-Warmth stance, whereas others may adopt a Low-Control-High-Warmth stance (Chung, 2005).

The total withdrawal of teacher control may discourage introverted students from participating in class, whereas too much control of teacher and use of textbooks may stifle participation or creativity altogether (see figure 10).

\section{Throw away your textbooks}

Dogme ELT argues that materials stifle the very communicative approach they are designed to drive. Luke Meddings on why he thinks the movement is as relevant as ever

Luke Meddings

guardian.co.uk, Friday 26 March 2004 12.25 GMT

Fig. 10. The news headline and scholar's argument against textbooks, Image source: The Guardian News

And so, teacher needs to make a precise adjustment of teacher role and the shift in focus of textbook use in order to make the activities in lessons more communicative. Specifically when teachers think about in what ways and manner to use communicative activities (adapted from textbook), they are advised to follow the following guidelines: 
1. "The activity must be purposeful and meaningful. Students should be given convincing reasons for doing the activity, and they should know what they will have achieved upon completion of the activity.

2. The activity must be authentic. The items taught in the activity must suit students' ages, habits, and environment. Students must be able to use the items for academic and non-academic purposes.

3. Teachers should feel free to adapt textbook activities.

4. Mechanical drills should not be the only activity in pair or group work.

5. A diversity of activities is needed."

(Cited in Yang and Cheung, 2003)

In above guidelines, point 3 reads that "Teachers should feel free to adapt textbook activities", and in point 4, it is stated that the "drills should not be the only activity" in group or pair activities. In using textbook, it is recommended to modify the activity given by the textbook designer. For example, based on the activity in Fig. 11, teacher can use additional games: teacher plays some interactive videos about different jobs, students are asked by teacher to describe the jobs in third-person way after the video, and the riddle format provided by the textbook can be a reference for students during the verbal description.

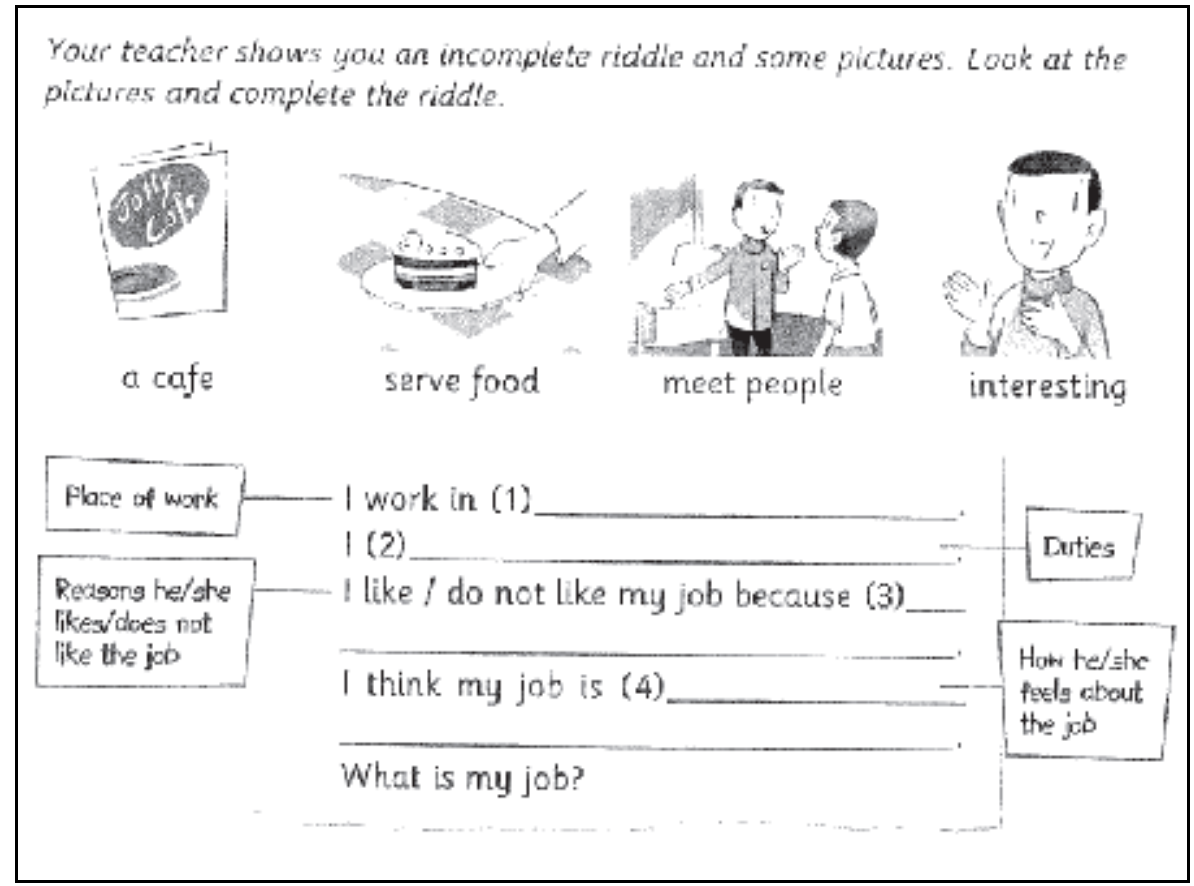

Fig. 11. Complete the riddle, Image source: New Magic 5A

Furthermore, teachers have to adjust some procedures of a game set in textbook if there is a game activity. For example, to deal with the set game in the textbook excerpt in figure 12, teachers can first divide the whole class into several groups; students are told to write their own riddles by groups and group mates need to elect a representative to present the finished riddles; the audience will guess the riddles. And so teachers turn the originally structural game into the communicative game because the above procedures replace the traditional chalk-and-talk manner that teacher always ordered students to do it quietly in lesson, or as individual homework.

\section{Job riddles}

Harry wants to play a guessing game with you. Read his riddlos. Write goil answers in the boxes.

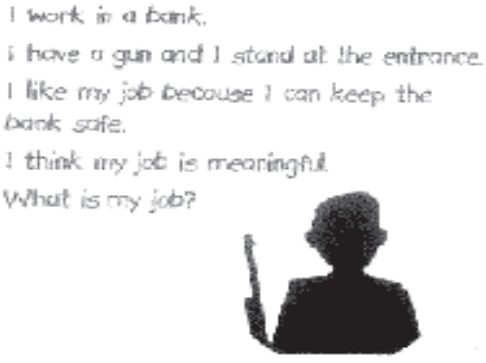

1 You are
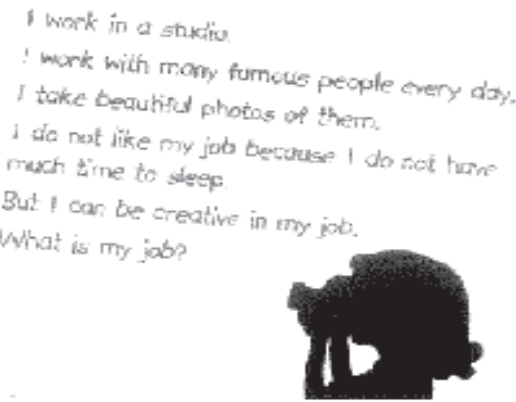

2 You are

Fig. 12. Job riddles as games, Image source: New Magic 5A 


\section{Conclusion}

This article has examined a number of selected textbooks mainly employed in Hong Kong and Malaysia, perhaps also in other places. A great deal of evidence shown in the textbooks excerpts has confirmed that the implementation of CLT in Malaysian, Hong Kong, and educational contexts of other regions or areas has limited influence on the teaching of grammar in textbook. This paper hence provided three communicative methods derived from the rationales for teaching using CLT approach to modify the activities in current textbooks which still retain structural teaching style; nonetheless we should note that the methods will only be effective on the condition that teachers possess the professional knowledge of incorporating CLT principles in their lessons.

\section{Acknowledgements}

My thanks to Dr Pretor Fok W. K. (having been the lecture in the School of Education and Languages, the Open University of Hong Kong; now the College Lecturer of the University of Hong Kong) for having provided me valuable comments on this paper.

\section{References}

Arnold, W. (2008). "What do you do?”. New Magic 5A. Oxford University Press (China) Ltd, unit 1.

Bachman, L. (1990). Fundamental considerations in language testing. Oxford: Oxford University Press.

Borich, G. D. \& Tombari, M. C. (1995). Educational psychology: A contemporary approach. New York: Harper Collins College, p. 302.

Canale, M. \& Swain, M. (1980). "Theoretical bases of communicative approaches to second language teaching and testing”. Applied Linguistics (1): 1-47.

Curriculum Development Council. (2004). English language education key learning area: English language curriculum guide (primary 1-6). Curriculum Development Council, pp. 211-212.

Chang, S.-J. (2000). "No more English-savvy dummies or fluent fools: A communicative approach of teaching English conversation”. English Teaching and Learning, 25(1), 40-59.

Chung, S. F. (2005). “A communicative approach to teaching grammar: theory and practice". The English Teacher Vol. $X X X I V, 33-50$. National Taiwan University.

Cunningsworth, A. (1995). Choosing your coursebook. Oxford: Heinemann.

Finocchiaro, M. \& Brumfit, C. (1983). The functional-notional approach: From theory to practice. New York: Oxford University Press.

Grant, N. (1987). Making the most of your textbook. New York: Longman, p. 79.

Howatt, A. P. R. (1984). A history of English language teaching. Oxford: Oxford University Press.

Hymes, D. H. (1971). “On communicative competence”. In: J. Pride \& J. Holmes (Eds.), Sociolinguistics (pp. 269-293). Baltimore: Penguin.

Jacobs, G. M. (in preparation). Making games cooperative.

Johnson, D. W., Johnson, R. T. \& Stanne, M. B. (2000). Cooperative learning methods: A meta-analysis. Cooperative Learning Center, University of Minnesota. Retrieved February 12, 2006, from http://www.co-operation.org/pages/clmethods.html.

Krashen, S.D. (1985). The input hypothesis: Issues and implications. New York: Longman.

Lee, W. R. (1979). Language teaching games and contests. Oxford: Oxford University Press.

Leung, C. (2005). “Convivial communication: recontextualizing communicative competence”. International Journal of Applied Linguistics, 15(2): 119-144.

Littlewood, W. (1981). Communicative language teaching. Cambridge: Cambridge University Press.

Littlewood, W. (1992). Teaching oral communication: A methodological framework. Oxford: Blackwell, p. 98.

Long, M. H. (1981). “Input, interaction, and second language acquisition”. In: H. Winitz (Ed.), Native language and foreign language acquisition (Vol. 379, pp. 259-278). New York: Annals of the New York Academy of Sciences.

Maley, A. (1986). "Xanadu- 'A miracle of rare device': The teaching of English in China”. In: J. M. Valdes (Ed.), Cultural bound: Bridging the cultural gap in language teaching. Cambridge: Cambridge University Press, p. 104.

Mauer, J. (1997, September). "Presentation, practice, production in the EFL classroom”. The Language Teacher, 21(9). 
Millis, B. (2005). "The educational value of cooperative games". IASCE Newsletter, 24(3), 5-7.

Ministry of Education. (1992). Kurikulum Bersepadu Sekolah Menengah Huraian Sukatan Pelajaran Bahasa Inggeris Tingkatan $I V$. Kuala Lumpur: Ministry of Education, p. 1.

Or, C.-W. (2010). An investigation of the presentation and treatment of vocabulary in two secondary English textbooks in Hong Kong. Unpublished dissertation, University of Hong Kong, p. 38.

Richards, J. C. \& Rodgers, T. S. (2001). "Communicative language teaching". In" Approaches and methods in language teaching (2nd ed.). New York: Cambridge University Press.

Rixon, S. (1981). How to use games in language teaching. London: Macmillan, p. 1.

Spaventa, L. (ed.) (1980). Towards the creative teaching of English. London: Allen and Unwin.

Suppiah, P. C., Subramaniam, S. \& Michael, A. S. (2011, October). "From trash to treasure: Grammar practice for the Malaysian ESL learners". Canadian Social Science, 7(5), 167-175. Canadian Academy of Oriental and Occidental Culture.

Swain, M. (1993). “The output hypothesis: Just speaking and writing aren’t enough". The Canadian Modern Language Review, 50, 158-164.

Thiagarajan, S. (1999). Teamwork and teamplay: Games and activities for building and training teams. San Francisco: Jossey-Bass.

Uberman, A. (1998, January-March). "The use of games for vocabulary presentation and revision”. Forum, 36(1), 2027. Retrieved February 12, 2006, from http://exchanges.state.gov/forum/vols/vol36/no1/p20.htm.

Ur, P. (1988). Grammar practice activities: A practical guide for teachers. Cambridge: Cambridge University Press.

Wright, A., Betteridge, D. \& Buckby, M. (2005). Games for language learning (3rd ed.). New York: Cambridge University Press.

Yang, A. \& Cheung, C.-P. (2003). “Adapting textbook activities for communicative teaching and cooperative learning”. English Teaching Forum, 41(3). Bureau of Educational and Cultural Affairs, Office of English Language Programs.

Yalden, J. (1987). Principles of course design for language teaching. NJ: Prentice Hall International, pp. 61, 94.

Yunus, N. A. \& Spykerman, A. (1996). KBSM English Form Four. Shah Alam: Fajar Bakti, pp. 211-212. 